\title{
MEASURING SATISFACTION USER WEBSITE WWW.Q0010.CO.ID USING DELONE AND MCLEAN MODELS
}

\author{
Yuyun Yuningsih ${ }^{1)}$, Ari Puspita ${ }^{2 *}$; Dahlia $^{3)}$ \\ ${ }^{1}$ Information Systems \\ Sekolah Tinggi Manajemen Informatika dan Komputer Nusa Mandiri \\ www.nusamandiri.ac.id \\ yuyun.yyg@nusamandiri.ac.id \\ ${ }^{2}$ Information Systems; ${ }^{3}$ Accounting information System \\ Universitas Bina Sarana Informatika \\ www.bsi.ac.id \\ 2ari.arp@bsi.ac.id ; ${ }^{3}$ dahlia.dlx@bsi.ac.id
}

\begin{abstract}
Abstrak
Penelitian ini bertujuan untuk mengukur kepuasan pelanggan atas pengunaan suatu produk atau jasa yang dijual pada situs belanja online yang dapat memenuhi kebutuhannya sesuai dengan yang di harapkan. Metode penelitian yang digunakan dalam penelitian ini adalah metode survei, penulis menyebarkan kuesioner kepada pria ataupun wanita berusia 17-40 tahun yang sudah pernah atau sering belanja online melalui website www.qoo10.co.id. Penelitian ini menggunakan model delone dan mclean dan dibantu dengan software AMOS (Analysis of Moment Structure). model delone dan mclean dapat mempermudah peneliti dalam menentukan variabel -variabel yang mempengaruhi dalam mengukur kepuasan pengguna website tersebut. Hasil dari penelitian ini adalah berupa bagan yang menyimpulkan bahwa kualitas sistem informasi berpengaruh terhadap kepuasan Pengguna.Kualitas sistem berpengaruh kepada pengguna, Kepuasan pengguna berpengaruh terhadap pengguna dan Pemakaian berpengaruh terhadap manfaat-manfaat dari web www.Qoo10.co.id dengan nilai Chi-Square 7,015 dan nilai Probability 0,83.
\end{abstract}

Kata Kunci: E-Commerce, Kepuasan Pelanggan, Model Delone and Mclean

\begin{abstract}
The research to measure customer satisfaction with the use of a product or service sold on online shopping sites that can meet their needs as expected. The research method used in this study is a survey method, the authors distribute questionnaires to men or women aged 17-40 years who have already or frequently shop online through the website www.qoo10.co.id. This research uses Delone and McLean models and is assisted with AMOS (Analysis of Moment Structure) software. Delone and McLean models can facilitate researchers in determining the variables that affect measuring website user satisfaction. the results of this study are in the form of a chart that concludes that the quality of the information system influences user satisfaction. The quality of the system affects the user, user satisfaction affects the user, and usage influences the benefits of the web www.Qoo10.co.id with the value of Chi-Square 7.015 and a Probability value of 0.83 .
\end{abstract}

Keywords: E-Commerce, Customers Satisfaction, Models Delone and McLean

\section{INTRODUCTION}

Technological advances are growing rapidly now, so the internet has become a necessity for many people to search for various information. Along with the development of technology, the term online store emerged as a popular website used for shopping. E-commerce applications greatly affect the quality of information, service quality, and system quality. (Dari \& Prahartiwi, 2020). Online shop is a website selling goods and services online (Agustin \& Koeshartono, 2014)

Online shopping is one of the most popular shopping alternatives for consumers today because they only need to connect to the internet, then open a website, and start 
choosing products to buy. Consumers do not need to leave the house to shop. One of the most popular websites today is www.qoo10.co.id, this website provides various products in the form of fashion, cosmetics, sports equipment, digital, home living, etc.

Online shopping site services make customers feel helped by practical buying and selling transactions and are considered cheaper than the prices of shops in the market, malls or other, but the services of the online shop can also cause technical problems that can make customers disappointed or dissatisfied, thus making customers look for other vendors to transact.

1) Problems that often arise in online shopping that can affect user satisfaction are:

2) Products from online shops sometimes have poor quality. The reason is very simple, the physical form of a product chosen is not noticed by the seller

3) Limited customer service. Meanwhile, problems with products or services received can occur at any time.

4) One problem people also fear when shopping online is about shipping. Long enough delivery makes customers dissatisfied. Sometimes the items ordered do not match the products described in the online store window. When you find something like this, the consumer has the right to return the items ordered to get a replacement for the goods that should be or transaction funds returned to the buyer. However, some online stores are troublesome and time-consuming when returning goods.

Customer satisfaction is the feeling of

liking or disliking someone on a product that matches customer expectations, and customer satisfaction is a positive or negative assessment of the services provided by the online shop. (Selviana \& Setyowati, 2019)

Previous research (Yuningsih, 2019) shows that information quality has a positive impact on customer satisfaction with an estimated value obtained 0.862, customer satisfaction also affects application users with an estimated value of 1.582 , and users affect the benefits of online shop applications with an estimated value of 0.837 .

Also, the results of research from Piarna in 2014 showed that the source of information and website quality has a very significant influence on customer confidence in using e- commerce sites but does not directly influence the decision to transact again (Piarna, 2014).

From the background and the results of previous studies, the purpose of this study is to measure user satisfaction on the website www.qoo10.co.id by using the Delone and McLaren models, the purpose of using this model makes it easier for authors to determine the variables that can influence in measuring website user satisfaction.

\section{RESEARCH METHODS}

The research methods used by the authors in research to write this journal are as follows:

a. Observation

The author makes observations to customers who make purchases using the website www.qoo10.co.id facility.

b. Literature review

In this study, the authors began the study by looking at the journals of previous researchers, and sources or other materials related to the research theme that the authors took To be used as reference material and reference in conducting this research.

c. Questionnaire

The next step is the preparation of the questionnaire. Data collected using this questionnaire include :

1) Data about the description of the respondent, which contains the sex and age of the respondent.

2) Data on respondents regarding the dimensions tested on user satisfaction on the www.qoo10.co.id site. At this stage, respondents were asked to answer many questions in 7 (seven) question sections.

The seven parts are :

a) Part 1 regarding respondent's data; b) Part 2 regarding E-Commerce Information Quality; c) Part 3 regarding System Quality; d) Part 4 regarding Service Quality; e) Part 5 regarding Use; f) Part 6 regarding User Satisfaction; g) Part 7 regarding Net Benefits.

\section{Types of research}

The type of research made by the writer is quantitative research by distributing questionnaires to the target research. (Sugiyono, 2009)

\section{Time and Place of Research}


The time needed for researchers to begin preparing, making, distributing questionnaires, and processing data are done by researchers from September to October 2019.

\section{Research Targets / Subjects}

The research targets are women or men aged 17-40 years, and the population taken as the object of this study is among students and community of East Jakarta who have or frequently use the website www.qoo10.co.id.

\section{Research Stages}

In this chapter the author explains the steps in conducting quantitative research as follows :

1. Stages of Preparation

At this stage is the stage to provide material relating to the satisfaction of users of the website www.qoo10.co.id formulation of the problem by gathering preliminary information to find out the background of the problem, identification of problems, goals and objectives, scope and hypotheses, and compile a literature study that related to research.

2. Stages of Data Collection

Data collection techniques used in this study were questionnaires, data collection techniques were used through questionnaires in line with the model used in this study

3. Stages of Data Analysis

In this study the authors use quantitative data, data analysis is an activity after data from respondents or other data sources are collected. Based on data about the quality of E-Commerce information, system quality, service quality, usage, user satisfaction with the Website www.qoo10.co.id.

4. Testing Stages

In the testing process, researchers have given questionnaires to expert respondents, then conducted data processing using structural equation modeling or Structural Equation Modeling (SEM) (Ghozali, 2008) with the help of AMOS software (Analysis of Moment Structure) (Santoso, 2015)

5. Stages of Results and Suggestions this section is the core stage of the entire description and discussion of research in the previous chapters and the advice needed in this study.

\section{Data, Instruments and Data Collection Techniques \\ 300 questionnaires were distributed to} 300 respondents. while the questionnaires returned by respondents to the writer were 250 questionnaires. Of the 250 respondents who returned this questionnaire were used as data for research material. Profile of research respondents can see in table 1 below

Table 1. Profile of Research Respondents

\begin{tabular}{lcc}
$\begin{array}{c}\text { Classification of } \\
\text { Respondents }\end{array}$ & Amount & Percentage \\
\hline Age: & 195 & $78 \%$ \\
\hline$>18$ thn & 55 & $22 \%$ \\
\hline$<=18$ thn & 250 & $100 \%$ \\
\hline Total & & \\
\hline Gender: & 146 & $58,4 \%$ \\
\hline Perempuan & 104 & $41,6 \%$ \\
\hline Laki-laki & 250 & $100 \%$ \\
\hline Total & & \\
\hline long time using: & 97 & $38,8 \%$ \\
\hline$>3$ thn & 153 & $61,2 \%$ \\
\hline$<=3$ thn & 250 & $100 \%$ \\
\hline Total & &
\end{tabular}

Data analysis technique

The data obtained by the authors through a survey when distributing questionnaires is in the form of opinions of website users who use the facilities provided by web qoo10 to make purchases through online ordering. This survey data is measured by Likert which is a fully ordinal scale. (Sugiyono, 2016) Another consideration is the use of a Likert scale is the maximum method and likeness that will be used in research because it will produce a valid and reliable parameter estimation value if the data used in the study meet multivariate normality. The format used by the author to compile a measuring instrument using the Likert format, which is a popular item writing format for attitude and personality scales, wherewith a writing format like this, the subject is asked to indicate the degree of agreement with the questions. On the scale above used scale 5 , meaning that each question allows 5 choices, with the following details :

The value 1 is at the far left of the scale line, reacting with the response "Strongly disagree" Value 2 at the left end after the value scale 1 , scale related to the response "Disagree" 
The value of 3 ends in the middle between scale 2 and scale 4, reacting with the response "Neutral"

A value of 4 ends to the right after scale 5 , scale related to the "Agree" response

Value 5 at the right end of the scale line, related to the "Strongly Agree" response

\section{RESEARCH RESULTS AND DISCUSSION}

\section{a. Initial Research Model}

An initial model of research to test hypotheses can be seen in the figure below: questionnaire. Data collected using this questionnaire include:

1) Data about the description of the respondent, which contains the sex and age of the respondent

2) Data on respondents regarding the dimensions tested on user satisfaction on the www.qoo10.co.id site. This stage is the respondent.

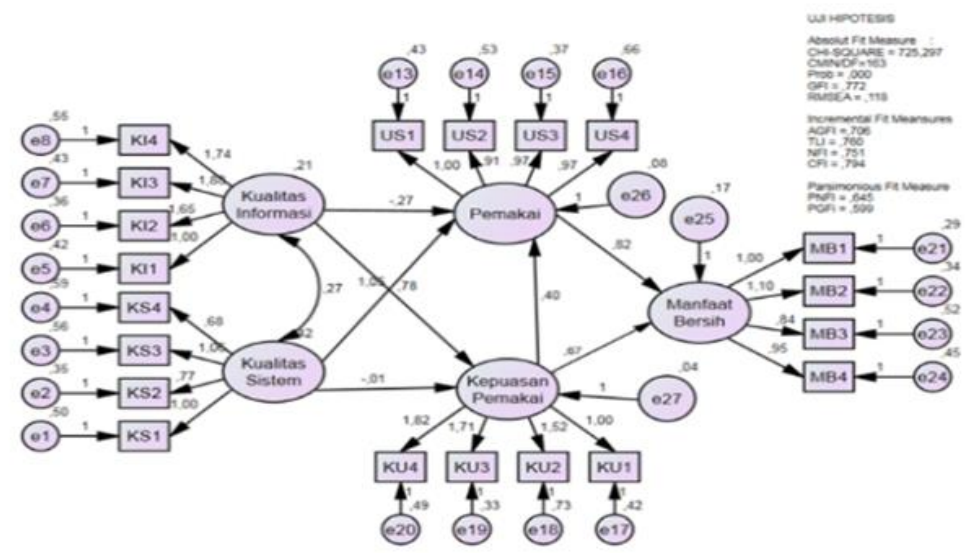

Figure 2 Initial Research Model

From Figure 2 above it is explained that the chi-square value of 725.2977, RMSEA 0.118, and Prob value of 0.00 . To get a fit model the GFI value should be above 0.9 because the GFI value on this model is 0.772 so that the initial research model is not fit. Also, if the connecting line between variables is less than 0.5 , it can be interpreted that between the 2 variables do not affect each other. For example, the connecting value between information quality and usage is
-1.93. Because there is no influence between the two variables, to get the fit results the connector is removed.

\section{b. Final research model}

From previous research models that are less fit and there are still some connecting lines whose values are below 0.5, then a further hypothesis test is carried out to obtain the results as shown in Figure 3 below:

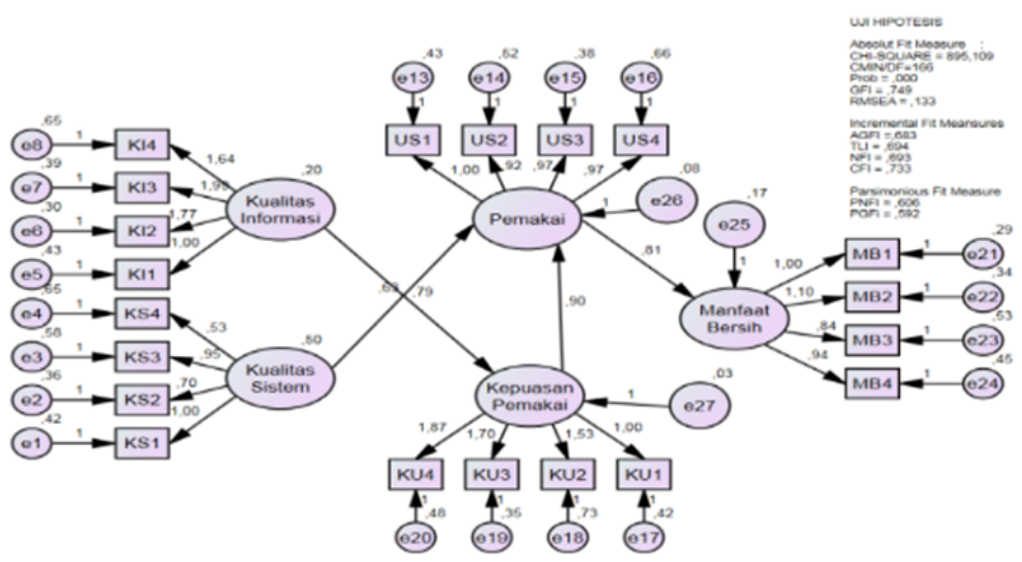

Figure 3 Final Research Model 
From Figure 3 above it is explained that the chi-square value of 895,109 , RMSEA 0,133 , Prob value 0,00 but do not meet the desired requirements $p>0.05$, and the GFI value in this model is 0.749 which should be above 0.9 , so this research model still fit. But because there is no longer a connecting line between the variables whose value is below 0.5 then this can be said to be the final model of the study.

\section{c. Research Pathways Analysis}

From the results of the above hypothesis test which results in a model that is not fit yet, then we do the Validity test using the path analysis as Figure 4 below:

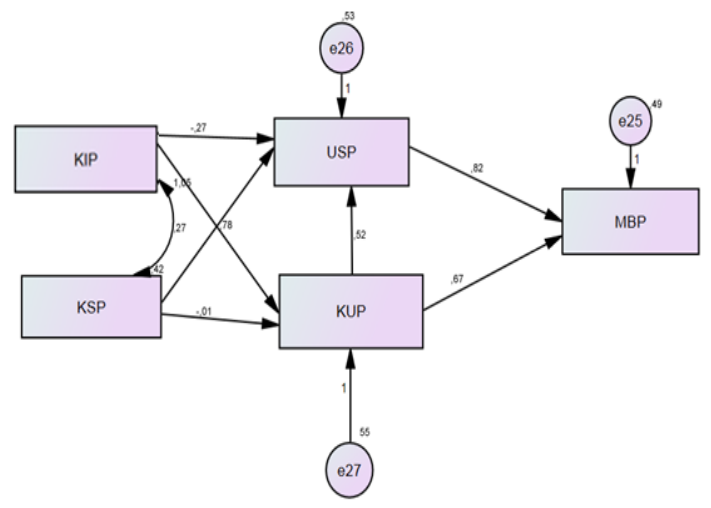

Figure 4 Test Validity Analysis Path

From the Figure 4 above the connecting lines between the variables, there are some connecting lines between the variables which have a value less than 0.5 then the model still cannot be said to be fit, but the results of the validity test output that have been carried out are as Figure 5 follows:

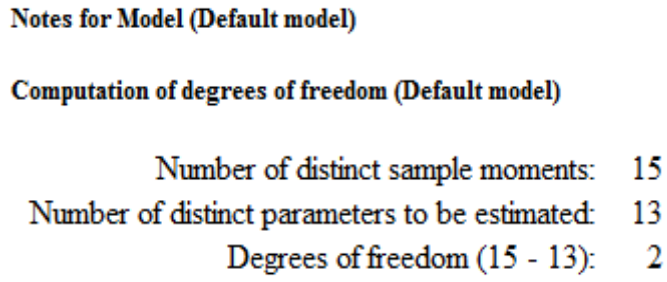

Result (Default model)

Minimum was achieved

Chi-square $=5,081$

Degrees of freedom $=2$

Probability level $=, 079$

Figure 5 Line Analysis Output
From Figure 5 it can be seen that the Probability value is 0.79 fulfilling the requirements with a minimum value of prob> 0.05 . But because there are still connecting lines below the standard requirements, a further validity test is performed.

\section{d. Final Model Path Analysis}

From previous research, to perfect the research results. Then a significant test is carried out to produce the final model of the study as shown in Figure 6.

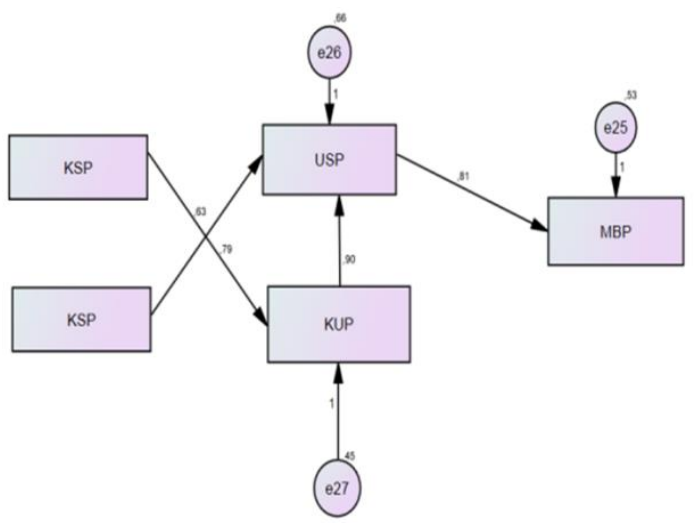

Figure 6 Final Research Path Analysis

From the picture 6 above the connecting lines between the variables have already met the requirements with all values $>0.5$, then this model can be said to be fit, and the results of the validity test output that have been carried out are as follows:

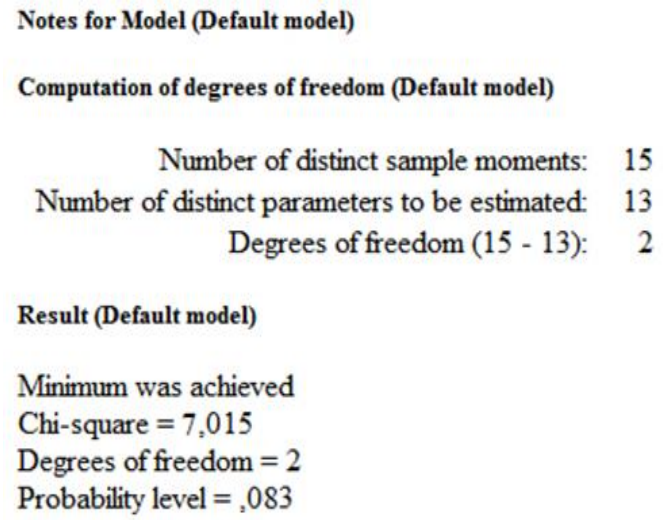

Figure 6 Output of Test Validity Analysis Final research path

From Figure 6 above it can be seen that the Probability value is 0.83 that meets the requirements with a minimum value of prob> 0.05 . 


\section{CONCLUSIONS AND SUGGESTIONS}

\section{Conclusion}

After doing a series of SEM data processing with AMOS, several problems were found which resulted in invalid SEM data processing. Therefore, the authors conducted a path analysis (path analysis) to get more valid research results. Based on tests conducted by path analysis, it can be concluded that the information quality affects user satisfaction, the quality of the system affects the user, user satisfaction affects the user, and Usage influences the net benefits of the web www.Qoo10 .co.id with a Chi-Square value of 7.015 and a Probability value of 0.83 .

\section{Suggestion}

The author's suggestion in this study is the need for training to use AMOS (Analysis of Moment Structure) software. Further research is expected to develop by adding criteria to make better decisions and tools used in addition to AMOS (Analysis of Moment Structure) with models other than Delon and Mclean. For future research to include other variables, it is expected to be able to significantly measure the frequency of users who shop on the web Q0010, so that research will be more varied and the data realtime.

\section{REFERENCE}

Agustin, J., \& Koeshartono, D. (2014). Kata kunci : Karakteristik website, kepuasan dan loyalitas A. LATAR BELAKANG. Manajemen, Program Studi Ekonomi, Fakultas Atma, Universitas Yogyakarta, Jaya, 1-14.

Dari, W., \& Prahartiwi, L. I. (2020). Consumer Satisfaction of Sorabel Applications Using the Delone and Mclean Method. PIKSEL: Penelitian Ilmu Komputer Sistem Embedded and Logic, 8(1), 21-30. https://doi.org/10.33558/piksel.v8i1.201 6

DeLone, W. H., \& McLean, E. (2004). Measuring e-Commerce Success: Applying The
Delone \&amp; McLean Information System Success Model. International Journal of Electronic Commerce, 9(1), 3147. Retrieved from https://www.researchgate.net/publicatio n/279894167_Measuring_e-

Commerce_Success_Applying_the_DeLone _McLean_Information_Systems_Success_M odel

DeLone, W. H., \& McLean, E. R. (2002). Information System Success Revisited. Proceeding. Proceedings of The 35th Hawaii International Conference On System Sciences.

Ghozali, I. (2008). Konsep \& Aplikasi dengan program AMOS 16.0. Semarang: Badan Penerbit Universitas Diponegoro.

Piarna, R. (2014). Pengaruh Sumber Informasi dan Kualitas Website terhadap Kepercayaan Pelanggan dalam Menentukan Keputusan Bertransaksi pada E-commerc e ( Studi pada Pelanggan E-commerc e di Indonesia ). Jurnal Aplikasi Manajemen, 12(1), 10-21.

Santoso, S. (2015). Structural Equation Modeling. Konsep dan Aplikasi dengan AMOS. Membuat dan menganalisis Model SEM Menggunakan Program AMOS 22. Jakarta: Penerbit PT. Elex Media Komputindo Kelompok Gramedia.

Selviana, \& Setyowati, R. B. (2019). Pengaruh Sikap Belanja Online Terhadap Trust Melalui Mediator Kepuasan Pelanggan, 3(74), 58-64.

Sugiyono. (2009). Metode Penelitian Kuantitatif dan Kualitatif. Bandung: Penerbit Alfabet.

Sugiyono. (2016). Metode Penelitian Kuantitatif, Kualitatif dan R\&D. Bandung: PT Alfabet.

Yuningsih, Y. (2019). Metode Delone dan Mclean Dalam Kepuasan Konsumen Terhadap Aplikasi Shopee, 6(1), 55-64. 